\title{
Effects of Carbohydrates Supplementation and Physical Exercise
}

\author{
Roscamp R and Santos $\mathrm{MG}^{*}$ \\ Department of Physical Education, Federal University of Paraná (UFPR), Paraná, Brazil
}

*Corresponding author: Roscamp R, Santos MG, Department of Physical Education, Federal University of Paraná (UFPR), Paraná, Brazil, Tel: (41) 9996 5822, E-mail: mariagisele@yahoo.com

Citation: Roscamp R, Santos MG (2015) Effects of Carbohydrates supplementation and Physical Exercise. J Nutr Health Sci 2(3): 303 . doi: 10.15744/2393-9060.2.303

Received Date: October 17, 2014 Accepted Date: August 25, 2015 Published Date: August 28, 2015

\begin{abstract}
Carbohydrates are the most abundant biomolecules on Earth. They are important for muscle contraction during prolonged exercise performing at moderate intensity and short duration exercise performed at high-intensity [1,2]. There is a considerable amount of studies related to the ergogenic effects of nutritional resources in sport performance [3]. Based on this evidence, this article aims to review the physiological and biochemical concepts and definitions of carbohydrates; searches for a relation between the consumption of carbohydrates and daily studies; and mainly analyzes the relations between consumption of carbohydrates and physical performance, analogously before, during and after the competition. To conduct the study was first done a widespread research looking for articles and scientific studies, and after that the research was filtered using up-to-date articles. The power of an athlete directly influences his physical performance [4]. In the pre-competition stage stored glycogen increases and prevents from depletion [5]. Supplementation during competition aims to replenish lost fluids and carbohydrates [6]. After a competition it is necessary to rehydrate, fill glycogen stores and recreate an electrolyte balance [3]. Literature reviews are important connectors that have been studied ..... where the science must advance. More research should be done to get to know the ideal carbohydrate intake appropriate for each sport.

Keywords: Supplementation; Carbohydrates; Exercise
\end{abstract}

\section{Introdution}

Carbohydrates, as the name suggests, are made up of water $\left(\mathrm{H}_{2} \mathrm{O}\right)$ and carbon, where hydrogen and oxygen are bonded together by a simple connection. They are the most abundant biomolecules on earth [2]. Carbohydrates are important for muscle contraction during performance of prolonged exercise at moderate intensity and high-intensity exercise with short duration [1]. Knowing this, the quest for improvement of the physical performance has increasingly led athletes to use dietary manipulation and nutrients intake. The maintenance of muscle glycogen stores is extremely important for high-performance athletes, where regular physical training and proper nutrition can positively affect the increase of these reserves [7]. Although it is clear that the increased use of nutritional supplements aims to muscle hypertrophy and improves the performance, many questions about the proper use of the supplements haven't yet been discussed. Due to evidences suggesting the importance of glycogen during performances, there is a great interest in maintaining inventories related with the level of glycogen in muscle and liver, thus it is generally recommended carbohydrate intake for athletes performing long term sports, due to their rapid metabolism [3]. Checking literature, we found a considerable amount of studies looking at the effects of nutritional ergogenic resources on exercise performance. Only in the 80s was conclusively demonstrated that ingesting carbohydrates during exercise can increase the athletes' performances. Also the correct and sufficient quantity of nutrients for athlete consumption [3,8] is discussed in nutrition.

A correct replenishment of carbohydrates should be performed especially for those practicing long-time sports, since a sharp decline in muscle glycogen concentrations $(130 \mathrm{~mm} / \mathrm{Kg}$ to $30 \mathrm{mM} / \mathrm{kg}$ ) leads to a drop in the performance [9]. In the light of this evidence, it appears that adequate carbohydrate supplementation during the phases of the competition becomes one of the best strategies for the improvement of physical performance. Moreover, one can also verify that athletes and coaches involved have difficulties in choosing the ideal supplement [3]. The present study aims to review the concepts of physiological and biochemical definition of carbohydrates.

\section{Carbohydrates: Review}

As the name suggests, carbohydrates are a compound of water and carbon where hydrogen and oxygen are bounded by a simple connection [2] and they are the most abundant biomolecules on earth. Carbohydrates are polyhydroxy-aldehyde or ketones, or also substances that liberate these compounds by hydrolysis. The carbon number may vary from 3 to 7 carbon atoms, and carbohydrates composed by 5 to 6 carbon atoms are the most thoroughly investigated, such as glucose, which contains six carbon atoms, 12 hydrogen and 6 oxygen [10]. There are still, according to [2], carbohydrates attached to nitrogen, phosphorus or [11]. These compose the main substrate energy of the cell, breaking down glucose aerobically and anaerobically. Other kinds of carbo- 
hydrates act as joint lubricant and participate in the recognition and cohesion of cells [2]. There are carbohydrates that are the staple food of certain regions of the planet. According to McArdle (2003) there are four categories of carbohydrates: monosaccharides, disaccharides, oligosaccharides and polysaccharides. These are differentiated according to the number of simple sugars forming each molecule [10].

\section{Monosaccharides}

They consist of a single unit of polyhydroxy-aldehyde or ketone. The number of carbons in the ring determines its category. Monosaccharides with more than 4 carbons tend to have cyclic structures. Hexose sugars are the major type (glucose, fructose and galactose) $[2,11]$.

Glucose (Figure 1) can be obtained in various ways, for example by carbohydrate digestion or gluconeogenesis. Fructose is obtained by the consumption of honey and fruit absorbed through the small intestine into the blood and released by the liver as glucose. Galactose is not found free in nature but in the manner that milk and sugar absorbed from the human body is also transformed into glucose. Vieira (2003), argues that starch, however, is the most common form of carbohydrate in a diet, representing about $90 \%$ of dietary carbohydrates $[10,11]$.

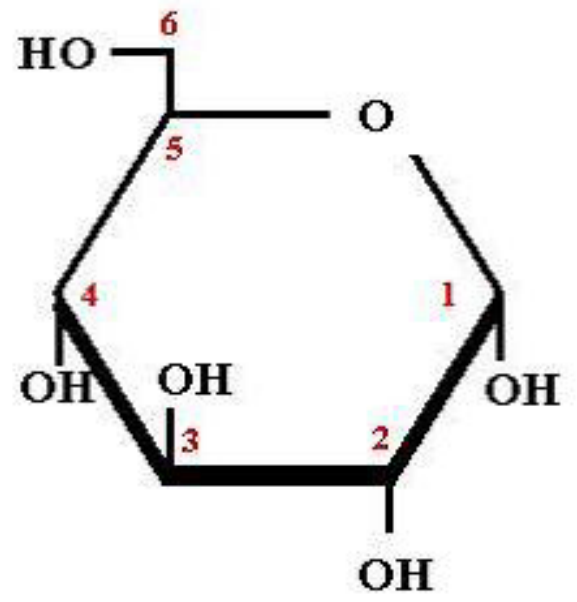

Figure 1: Glucose Structural Form (Vieira, 2003)

\section{Disaccharides and Oligosaccharides}

Disaccharides are the combination of two molecules of monosaccharides covalently joined by an O-glycosidic bond which forms itself from the reaction of a hydroxyl group of sugar molecules with a carbon atom belonging to another molecule of sugar. All disaccharides present glucose as main component, for example sucrose (glucose + fructose) - is the most common representative of this group [2]; Lactose (glucose + galactose) - commonly found in milk and important for high energy, especially in the first years of life, regarding mammals [11] (VIEIRA, 2003); Maltose (glucose + glucose) - found in cereals and seeds at the germination stage, contributes just a little to the diet of a person.

Oligosaccharides consist of short chains of monosaccharide units, or monosaccharides united to some residues found in vegetables (vegetable seeds), joined by glycosidic bonds [2,10].

\section{Polysaccharides}

This association made up of ten to thousands monosaccharides through glycosidic linkages, classified from plants and animals, are often found in nature [2,10]. Polymers contain more than 20 monosaccharide units and may have chains containing hundreds of monosaccharide units [2]. Polysaccharides are differentiated by the number of monosaccharide units, the types of connection between them, the length of the chains and the chain branching degree. This can be classified into homopolysaccharides and heteropolysaccharides. The first occurs when there is a single type of monomeric unit, for example starch and glycogen, and the others when there are two or more types of units. In animal tissues the heteropolysaccharides comprise the extracellular space, providing protection and maintaining united a cell to another [2] Polysaccharides contained in vegetables are represented by starch and fibers. The first is the storage form of carbohydrate in plants, appearing abundantly in seeds, corn, peas, and beans, among others. Starch is divided in two types according to its molecular structure, which are amylose - the longest straight chain of glucose units present in a helical coil and amylopectin linked to monosaccharide highly branched. The prevalence of one or another determines the digestibility of the food. Those with higher amylopectin are digested faster compared to food with a prevalence of amylose [12]. The fibers have received special attention from researchers in recent years showing an inverse relation of their higher consumption towards reduction of obesity, diabetes and hypertension. The fiber retains water giving a greater amount and greater volume of food waste, that can lead to an improvement in gastrointestinal function by accelerating intestinal transit which forms a sort of scraping on the walls preventing thereof chemicals, harmful to the body, to remain there longer. A 
higher intake of fiber can reduce the chance of contracting colon cancer, in addition to a better control of serum cholesterol helped by eating water-soluble mucilaginous fiber contained in flours, legumes, barley and brown rice [2]. For Berg (2007) animal polysaccharides are represented by the glycogen polymer consisting in a large format and irregularly branched and they are commonly found in muscles and liver of mammals with the function of storing glucose [13]. According to McArdle (2003), muscle glycogen is the immediate source of energy for working muscle coming from carbohydrates. Liver glycogen undergoes a longer process to supply energy to the muscles [10]. It turns into glucose by the action of the enzyme phosphatase (glycogenolysis) which is transformed through the bloodstream into the muscle in exercise. The breakdown of muscle and liver glycogen by diet or by strenuous exercise causes to the body a quest in order to synthetize glucose by other nutrients such as amino acids, process also known as gluconeogenesis.

The breakdown of the carbohydrates to monosaccharides in the stomach and in the small intestine provides glucose as predominant product along with galactose that is absorbed by an active mechanism of transport [14]. Glucose is the most important monosaccharide, since most of the carbohydrates are broken down until reaching the glucose transported by the blood, whereas fructose is converted by the liver into galactose and glucose [15].

Regulation and maintenance of concentration levels of glucose in the blood are mediated by hormones. With high levels of blood sugar, insulin is activated by the action of pancreatic beta cells forcing the excess of glucose uptake by the cells. Otherwise, glucagon can be enabled (this time, by the action of pancreatic alpha cells) to stimulate glycogenolysis and gluconeogenesis in order to raise the level of blood sugar [10]. According to Lancha (2002) glucose that goes into blood stream is converted into muscle or liver glycogen, and the amount absorbed in excess is converted into fatty acids and triglycerides in liver and adipose tissue [11]. In addition, during exercise involving endurance, glucose level in the blood must be maintained high.

\section{Carbohydrates and Physical Exercise}

It is known that athletic performance depends on numerous factors including, proper nutrition and training. The first is very important, because without an optimal nutrition throughout the athlete's training it may be impaired [16]. The power of an athlete directly influences his physical performance, thus a sportsman's performance depends on the availability of carbohydrates in his body [4]. The production and resynthesis of energy in the body depends primarily on the exercise and on the contribution of two macronutrients: liver and muscle glycogen; triglycerides in adipose and muscle tissues. Mcardle (2003) shows that this production is determined primarily by fat metabolism at rest $(60 \%)$, being predominant in endurance exercise by carbohydrate metabolism [10]. The catabolism of glycogen is the primary mean used to obtain energy in order to exercise the change from low to high intensity which can quickly supply the ATP during oxidative processes. Mamus (2004) have found that the amount of available carbohydrates is crucial to regulate fat metabolism in exercise. The increased oxidation of carbohydrates caused by eating foods with a high glycemic index, which increase blood glucose levels and the rate of blood insulin, significantly dampens the breakdown of free fatty acids from adipose tissue during exercise [17].

Grandjean and Shroeder (1994) Suggest that athletes should consume a diet that provides the basic nutrients and rich in carbohydrates to supply energy needs, especially athletes who practice long-duration activities [18]. According to Lancha (2002) and Mullinix (2003) [9,19] one of the biggest problems encountered today is the low carbohydrate intake by athletes which causes drop in income in the period of training and especially in competition.

Rogatto (2003) Says that carbohydrate intake has a strong relationship with yield obtained through physical exercise [20]. An adequate dietary intake of carbohydrates can be decisive for the athlete during the competition, and it may be responsible for his defeat or victory. Besides the dietary manipulation and the training conducted in the week prior to the competition, other factors may influence the ability of the athlete to maintain the muscles active. Mamus, et al. (2004) argues that during the training is necessary a rich supply of these nutrients in order to succeed in the competition, because it is during this period that increases the energy expenditure and consequently occurs an increase in caloric intake to maintain the body weight and the correct functioning of the body [17]. For example Dill, et al. (1932), studied the effects of carbohydrate intake in a race using a trained dog at the right intensity [21]. Quickly, the dog was able to run from 3 to 6 hours before tiring itself, a fact that coincided with the decrease of glucose concentrations in its blood. When powered by carbohydrate before and during exercise, it was able to run over 13 hours. The authors then concluded that the yield of prolonged exercise could be associated to the availability of carbohydrates in the form of available glucose. Therefore the intake of carbohydrates was able to delay fatigue in the dog. Kreider (2010) describes that individuals involved in a program of general fitness, can require the consume of macronutrients in a normal diet (ie, 45$55 \%$ CHO [3-5 grams/kg/day] PRO 10-15\% [0.8-1.0 g/kg/day] and 25-35\% of fat [0.5 - $1.5 \mathrm{~g} / \mathrm{kg} /$ day]) [22]. However, according to the authors, athletes involved in moderate and high volume training need greater amounts of carbohydrates and proteins in their diet to satisfy the need for macronutrients they have. For example, in terms of carbohydrates requirement, athletes involved in moderate amounts of intense training (for example, 2-3 hours per day of vigorous exercise performed 5-6 times per week) normally need to consume a diet composed of 55-65\% of carbohydrates (i.e. 5-8 g/kg/day or 250-1200 g/day 50-150 kg). 
Mcardle (2003) shows, in neural-hormonal factors, that intense exercise accelerates the production of adrenaline, noradrenaline and glucagon (conversely, a reduction in insulin production) [10]. Thus, there is an activation of the enzyme that phosphorylates glycogen, which accelerates the breakdown of muscle and liver glycogen. In the first minutes of exercise, when oxygen cannot meet the demand for energy, muscle glycogen becomes the primary source, because it does not need oxygen to produce energy. The uptake of circulating glucose increases markedly according to the intensity of the exercise (light - 25-30\% of VO2max; moderate - 50-60\% of VO2max; 75-90\% of VO2max). For example, one hour of high-intensity exercise reduces liver glycogen by 55\%. The increase in glucose uptake in about 40 minutes of exercise can be between 7-20 times more than the same uptake at rest, advantage that depend on the fact that carbohydrate metabolism transfers power twice faster than fats and proteins. Compared with the only difference that fats have $6 \%$ more energy production than carbohydrates.

Several studies (Lancha., 2002; MCARDLE, 2003; Timmons et al., 2003) show that, as the exercise follows and glycogen decreases, blood glucose becomes the primary source of energy of carbohydrates $[9,10,23]$. Plasma glucose concentration drops after a certain period because the liver cannot keep up the use of glucose by the muscles. With 90 minutes of strenuous exercise, blood glucose levels can be reduced to less than $45 \mathrm{mg}$ of glucose per $100 \mathrm{ml}$ of blood, so it may occur hypoglycemia and yield decrease. Proofing a marathon is a classic model to explain carbohydrates metabolism.

According to Silveira (2011) VO2max runners have exceptional ranging between 70 and $85 \mathrm{~mL}^{\mathrm{kg}} \mathrm{kg}^{-1} \cdot \mathrm{min}^{-1}$. These athletes run a marathon at intensities below the VO2max, as noted above, in events lasting 10-15 min [24]. It is estimated that many of the 42 $\mathrm{km}$ of a marathon are traversed in approximately $75 \%-85 \%$ of VO2max. During this type of event, the oxidation of glucose and fatty acids is estimated to occur in a ratio of 7: 3; three fatty acid molecules are oxidized for every seven glucose molecules [25]. Under these conditions, the oxidation of lipids favors the continuity of muscle activity for a long period. If not, glycogen stores are rapidly depleted compromising the continuity of the activity. It is important to note that the relative rate of glucose oxidation is higher (7: 3) than the lipid one, demonstrating the importance of entering carbons in the tricarboxylic acid (anaplerosis) at the expense of the carbohydrate cycle. It is also known that an elite of athletes (Olympic level) can achieve an even higher ratio of carbohydrate/lipid, predominantly using carbohydrates during endurance exercise and remaining close to $90 \%$ of VO2max intensities, confirming the predominance of carbohydrates utilization [26].

Therefore, these athletes are more successful in Marathon tests because they can maintain a high rate of glucose oxidation per unit of time (oxygen uptake). As reported by Joyner (2008) and Spriet (2007), a high capacity to store glycogen associated with a high mechanical efficiency is crucial for the performance of these athletes [26,27]. The carbohydrate depletion leads to a decrease in work capacity that after two hours progressively loses $50 \%$ of the initial intensity. This reduced level of work is directly connected with the production and the release of energy by the oxidation of fats, which are replaced primary role in energy production in this period. Thus, it is necessary to replace carbohydrates throughout the competition (pre, during and post) considering type, concentration and form of the carbohydrate intake $[10,17,23,28]$. A proper carbohydrate intake is essential for optimizing the initial glycogen stores in muscles, maintaining blood glucose levels during the exercise and ------ an adequate replenishment of glycogen stores during recovery (American Dietetic Association, Dietitians of Canada, American College of Sports[29].

The recommendations of carbohydrate for athletes are 6-10 g/kg of body weight per day or 60-70\% of daily energy intake, however, the individual need will depend on sport energy expenditure, sex of the athlete and environmental conditions [30].

\section{Pré-Competition Supplementation}

The goal of a high-carbohydrate diet in pre-competition phase is to increase stored glycogen and prevent from its depletion when the training is conducted thoroughly successive days, requiring, to improve the performance, a diet with $65-75 \%$ of calories coming from carbohydrates $[5,14]$. Depending on the pre-training situation, this intake can reach $80 \%$ of total energy calculated as necessary [10]. For Katch (2003) resilience varies strongly according to the carbohydrate diet used before exercise which, besides providing sufficient energy to the athlete, should also ensure hydration [31]. Mamus (2006) describes that the carbohydrate-based foods can be offered in solid or liquid form, the ideal recommended dosage of 1 to $6 \mathrm{~g} / \mathrm{kg} / \mathrm{body}$ weight [5]. According to Walton \& Rhodes (1997), this type of intake in liquid form is recommended in order to reach a better physical performance during sporting event [32]. However Wolinsy \& Hickson Jr. (1996) argue that liquid meals are more tolerated close to the training or competition time [14].

Sapata (2006) says that energy drinks ingested before are intended to prevent or delay the homeostatic disturbances that can accompany physical activity, ensuring an adequate plasma volume since the beginning of the year, promoting a small reservoir fluids in the gastrointestinal lumen, which will be absorbed during the activity [33]. Also, for Wolinsy \& Hickson Jr, (2002) consumption during pre-exercise may potentiate glucose concentrations in the circulating blood, by providing carbohydrates [34].

To Sapata (2006) the effect on metabolism and performance caused by consumption of carbohydrate drinks in pre-exercise is still questioned [33]. The author sought to elucidate the effects of prior consumption of beverages with different types of carbohydrates before exercise on an ergometer cycle with a fixed intensity at the second ventilator threshold. Thirty minutes before starting the exercise, the volunteers ingested $250 \mathrm{ml}$ of one of three different drinks (placebo, maltose, glucose) defined through a previous study. Volunteers showed no changes in their blood glucose during the period before and after 30 minutes from the ingestion of 
the placebo and glucose unlike the glycemic response after the consumption of maltose drink. Therefore, as well as in [35,36] have found that consumption of carbohydrate beverage 30 minutes before exercise, composed of simple or complex carbohydrates and both solutions with a high glycemic index, did not affect the exercise performance when compared with the ingestion of carbohydrate beverages without placebo. In Hargreaves' study et al. (1985), the consumption of carbohydrates with a high glycemic index, 45 minutes before exercise, did not cause effects on the performance, regardless of the glycemic response [37]. Foster, et al. (1971) demonstrated that consumption of $75 \mathrm{~g}$ of glucose 45 minutes before a relatively intense exercise ( $84 \%$ peak) can be associated with a decrease in time until exhaustion, compared with a mixed meal or control [38].

Kirwan, et al. (2001) analyzed the consumption of a meal with complex and high glycemic index 45 minutes before exercise. The result was that, after 30 minutes, the glucose consumption increased. After that, there was a decrease in blood glucose until the end of the test [39].

In the study carried out by Gleeson (1986), as in when compared, the groups who ate meals with high glycemic index, low glycemic index and placebo, were found no significant changes in their blood lactate measure widely used to predict the performance of the year $[35,40,41]$.

Otherwise, Cherrinton (2002) and Tappy (2006) demonstrated that fructose added to a glucose supplement, increases the levels of lactate at rest $[42,43]$. De Sá, et al. (2007) argues that fructose, which has a low glycemic index, a metabolism independent of insulin with a rapid hepatic uptake, presents important features that support his statement as a pre-workout supplement, in addition of assessing improvement during the performance and prolonging the time that it takes to exhaust [44]. Jeukendrup, et al. (2006) justifies the possible mechanisms involved in improved performance including a greater use of exogenous carbohydrates with a consequent saving of muscle glycogen [45].

Based on this, Rodriguez (2004) sought hypotheses about the nutritional variables and the performance of athletes of long-term activities [45]. In this study two different types of carbohydrates were applied in four trained cyclists with the mean age of 21.5 years $( \pm 2.1)$ and a body weight of $65.9 \mathrm{~kg}( \pm 3.9)$, which passed the Peak Power output to determine the maximum power of each. After that, each player participated in three trials, with intervals of 3 to 7 days and with a power between 50 and $60 \%$ PPO. An hour before the race, on a controlled group, fast absorbing carbs were applied on athletes (fasting) and on the other group were applied complex carbohydrates. After this, they were ready for the race, which consisted of pedaling between $50-60 \%$ of PPO for 120 minutes. During the race, was consumed, an isotonic solution with 55 grams of simple carbohydrate per liter of fluid. Finally, Rodriguez (2004) found that in those athletes who previously consumed simple carbohydrates, blood glucose level rebound between 30 and 40 minutes. Otherwise, athletes consuming a complex carbohydrates advantage demonstrated normal end time of about 5 minutes compared with those of the first group [46].

Smith, et al. (2002) conducted a study with triathletes providing pre-exercise glucose solutions, to determine the effects that time of administration has [47]. Triathletes swam $4000 \mathrm{~m}$ after consuming a 10\% glucose 5 mins (G5), 10\% solution 35 minutes before glucose (G35) or a similar amount of placebo (PL). It was found that the solutions (G5 and G35) resulted in individual performance improvement, were comparable with placebo (PL). Chryssanthopoulos, et al. (2002) have found the effects that preexercise ingestion of a meal and a solution of carbohydrate (maltodextrin) have on 10 marathoners during their performances [48]. As a test, a run at $70 \% \mathrm{VO} 2$ max until exhaustion was made after the consumption of a CHO meal three hours before exercising and an ingestion of a $\mathrm{CHO}$ solution during the exercise or $\mathrm{CHO}$ meal three hours before and just water during the exercise. It was concluded that the treatment with water during exercise performance showed better results, but the combination of meal and carbohydrate solution increased capacity. A growing number of participants in long-term and similarly, there are clear advances of science in pre-competition nutrition. Still, there are now several studies seeking for new nutritional interventions by carbohydrates and lipids. Wilmore and Costill (2001) argue that ultra-endurance athletes may have problems in balancing energy consumption with demand, which leads many of them to be concerned more with quantity than with the quality of what they consume [49]. Many of these athletes are looking for a "magic food" that would promote them to a winning performance. Researching some cyclists during a competition, Garcia-Roves, et al. (1998) observed that athletes consumed a certain quantity above the recommended amount of lipids, coming from cookies and candy, a low volume of fluid and amount of carbohydrates below recommended, the authors concluded that nutritional education of athletes, mainly as the fluid intake is the best way to proceed so that they can succeed as more as possible [50]. Clark (1998), among other studies, argues that due to the large energy expenditure in training, the ultra-endurance athletes should consume $70 \%$ or more of carbohydrates in their diet, especially the week before the competition [51]. Ferreira (2001) complements the statement verifying that currently, it is preferable to recommend the consumption of carbohydrates in grams per kilogram of body weight, and the amount estimated for ultra-endurance athletes would be 7-10 grams per kilogram of weight [52].

Lambert, et al. (1997) suggest that dietary lipid-based adaptation (meals containing more than $70 \%$ fat) from 2 to 4 weeks prior to ultra-endurance events with an intensity that goes from slow to moderate $(<70 \% \mathrm{VO} 2 \mathrm{max})$ may improve performance [53]. Hawley, et al. (1998) reported that endurance athletes trained using energy substrate during submaximal exercise (60\% VO2max) can be significantly altered by eating a diet rich in fat and low in carbohydrate $(60-70 \%$ and $15-20 \%$, respectively) for a period from 7 to 10 days [54]. 
Jeukendrup, et al.(1998) recommend caution in prescribing a high fat diet, since there is a little evidence about the effects of this intervention on the athletes' long-distance performance [54]. The current recommendations are based on the potential benefit of prescribing low-glycemic carbohydrates (LGC), between 1-2 g. $\mathrm{kg}^{-1}$ pre-event between 1-3 hours before, for greater efficiency [6].

\section{During Competition Supplementation}

Nutrition is an important tool within the sport, because, when well targeted, can reduce fatigue, allowing the athlete to train longer or recover better between workouts [55]. In the middle ' 80 s several studies have shown a direct relationship between the income and the consumption of carbohydrates. From here on, the research focuses on investigating the points of greatest vulnerability, like an optimum amount of consumption, type and time of ingestion of these carbohydrates, in order to maximize athletes' performance in different exercises [56].

In a review, [57] suggested replacement calculated on the relative use of carbohydrate from the energy supply for each physical activity. In moderate-intensity exercise, where about $50 \%$ of energy expenditure occurs through oxidation of carbohydrate with a caloric expenditure of $12 \mathrm{kcal} / \mathrm{min}^{-1}$, it would be required $1.5 \mathrm{~g}$ of carbohydrates per minute, which corresponds in replacement to $45 \mathrm{~g}$ of carbohydrates every 30 minutes of exercise.

Burke (2001) argues that no matter what you consume before exercise as long as during the exercise, kept at a moderate intensity, will be consumed sugar in liquid form with an high glycemic index [58].

Sapata (2006) describes that carbohydrates used during exercise can improve athletic performance [34]. According to Ferreira (2001) studies, it is described that there are few energy expenditure and food intake during competitions, due to methodological difficulties related to data collection [53].

Tarnopolsky (2000) and Jeukendrup (2005) have found that women, compared with men, proportionately oxidize more lipids and less carbohydrates and proteins during long-duration exercise. Thus, it can be stated a possible gender difference in the recommendation of macronutrients for long term sports $[59,60]$.

In contrast to these studies, Zderic (2002) and Lavoie (2004), among others, show significant differences in their studies, about the ratio of substrates used during exercise, for men and women $[61,62]$.

In the study of Viebig (2010) it appears that carbohydrate supplementation during exercise and specifications of it may vary among researchers [7]. The author advocates their use in the prevention of hypoglycemia and against reduction of athletes' performance during exercise, where consume of carbohydrates should be equal to the amount of carbohydrates used. This factor was studied by Riddell (1999), who used a sample of 20 adolescents with type 1 diabetes who exercised for an hour ingesting water or drink with $6-8 \%$ of carbohydrates [63]. This study found that in the group that consumed carbohydrate drink, blood glucose was not significantly reduced. However, the group that received only water was not at risk of hypoglycemia.

For Ferreira (2001) the major concern of ultra-endurance athletes is to maintain a pace considered ideal throughout the race. So in addition to a well-directed physical training, the athlete needs to consume an adequate amount of energy to sustain the demand of physical effort [52].

According to Miller (1996), energy expenditure during a competition varies from $5.000 \mathrm{kcal}$ (triathlon with $2 \mathrm{~km}$ swim, $90 \mathrm{~km}$ cycling and $21 \mathrm{~km}$ running) up to $18,000 \mathrm{kcal}$ (race 24 hours in duration) [64].

Goetzsche and Peters (1997) followed 150 men and 23 women who participated in a 90km Ultra Marathon and observed that energy consumption increased in men from 2.405 to $3.048 \mathrm{kcal}$ (50 to $57 \%$ of carbohydrates) and in women from 1.786 to 2.167 $\mathrm{kcal}$ (49.5 to $56.4 \%$ carbohydrate) [65].

Stroud (1998) cites an energy expenditure of $6.430 \mathrm{kcal}( \pm 1,190)$ per day for seven days, a proof of 240km through the Sahara Desert [66]. McArdle, et al. (1999) has already exemplified the average energy expenditure during the 'Tour of France' that was $6.500 \mathrm{kcal} /$ day, reaching $9.000 \mathrm{kcal} /$ day in the mountain stages, and the energy expenditure of an Ultra-Marathon of $1.000 \mathrm{~km}$ for 5 days which average was $59.079 \mathrm{kcal}$ with a daily expenditure ranging between 8,600 and $13.770 \mathrm{kcal}$ [67].

Through advances on studies about nutritional resources, Ferreira (2001) have found that carbohydrates present in sport bars, and stockers gel in energy drinks (which are also electrolyte replacers) further effectively enhance performances, before and during competitions [52]. And yet, according to the author, the concentration of carbohydrates in these repositories varies between 40 and $80 \%$, being mainly composed of malt dextrin, glucose, sucrose and fructose, which quickly provide large amounts of available energy. Moreover, this kind of replenishment can be found under several flavors, from chocolate to fruit, which pleases most athletes. However, Clark (1998) cites that athletes need to be completely adapted to this type of replenishment, since high concentration of this type of carbohydrates that give taste and other nutrients contained in them usually cause problems to stomach and intestine during competition [51].

During the competitive period [68] have found a high intake of protein supplements such as isolated amino acids, complexes of amino acids and creatine, among an elite of swimmers. Furthermore, the average dietary protein intake between these athletes was above the recommendations. However, although the average carbohydrate intake was within recommended levels, most athletes had insufficient intake of this nutrient. 
Paschoal \& Amancio (2004) evaluated the dietary intake of soccer players undergoing through intense training regimes (three to four hours/day), and observed a pattern of food consumption fractionated (four to six meals/day). In this study, analysis of the diets showed inadequate intake of Carbohydrates ---total energy [69].

Ziegler, et al. (2002), advocate eating small, frequent meals of an adequate energy density and nutrients which may assist the athlete in satisfying its nutritional needs, and at the same time, preventing gastrointestinal disturbances during exercise and excessive food intake, avoiding fatigue [70].

Currently, the main goal is to replace the loss of fluids and carbohydrates, supply 30-60 $\mathrm{gh}^{-1}$, critical especially for athletes involved in endurance over one hour in length; when the athlete haven't previously consumed an adequate amount of food or fluid, or when the athlete is exercising in an extreme environment (hot, humid or high altitude) [6].

\section{Post-Competition Supplementation}

Consumption after exercise of solutions containing carbohydrates is recommended by the Brazilian Society of Sports Medicine in order to facilitate maximum resynthesis of muscle and liver glycogen. The initial goal of the diet after a competition is to rehydrate, restore glycogen stores and restore electrolyte balance [3]. The main aspect of the recommendations focuses on the synthesis of glycogen to replenish the energy substrate been oxidized during exercise [6].

As this process is dependent on the supply of carbohydrate and insulin concentration, those with moderate to high GI are the most related to the efficiency of this metabolic process [22].

To replenish glycogen stores is indicated carbohydrate intake of $1.5 \mathrm{~g} . \mathrm{kg}^{-1}$----- 30 minutes and again after 2 hours for a period that goes from 4 to 6 hours. In an interesting study by Starling, et al. (1997), some subjects ingested a diet high in carbohydrates (83\%) or high lipid content (68\%) 12 hours before an exercise bout on a cycle ergometer at $65 \%$ VO2max for $120 \mathrm{~min}$. After 12 hours of fasting, a muscle biopsy and a session corresponding to $1.600 \mathrm{kj}$ exercise was performed [71]. Fats intake increased intramuscular triglyceride concentration by $21 \%$, unlike the high carbohydrate diet. In parallel to these results, the muscle glycogen concentration after the high-carbohydrate diet was higher when compared to a diet rich in lipids, resulting in a better performance in fiscal $1.600 \mathrm{kj}$.

According to Vieira (2007), as the reserves of glycogen in the body are limited, it is imperative a diet rich in carbohydrates immediately after exercise, and simple type of high glycemic index with a concentration ranging from 0.7 to $1.5 \mathrm{~g} / \mathrm{kg}$ body weight per hour and for a period of at least 4 hours [72].

Mcardle, et al. (2003) shows that after exhaustive prolonged exercises are required at least 48 hours for the recovery of normal levels of muscle glycogen [10].

GLUT-4 is responsible for removing up to $85 \%$ of plasma glucose, aided by insulin, which stimulates glucose transport into 30 times $[28,73]$.

Nakatani (1997), says that exercise increases rate and magnitude of glycogen super compensation after exercise, increasing the response between glycogen depletion during exercise and the time of glucose replacement [74].

For Vieira (2007) this fact is caused by no increase in the concentration of GLUT-4 protein in muscle, associated with the proportional increase in glucose transport capacity, evidenced by the increase in insulin sensitivity [72].

In the study of Greiwe (2000) it was found that endurance exercise in a cycling form increases between $32-51 \%$ the concentration of GLUT-4 until 22 hours after the exercise [73].

According to Lancha Jr's description (2002), immediately after and up to 2 hours after the end of the exercise, complex glycogen synthetized reaches an activity of $7-8 \mathrm{mM} / \mathrm{kg}$ per hour, a rate about $50 \%$ greater than that observed in the total period of 24 hours; and drops to $5 \mathrm{mM} / \mathrm{kg}$ per hour after two hours from the end of the year, but it is stressed, essential for optimal substrate availability [9].

Jentjens and Jeukendrup (2003) define that glycogen synthesis in recovery occurs in a biphasic manner. In the fast phase, which lasts between 30 and 60 minutes, the synthesis can be processed without the presence of insulin, increasing the permeability of the cell membrane occurs due to the displacement of GLUT4 molecules. After this phase, glycogen is synthesized slowly presenting insulin [75].

According to Ivy (2004), after the effort, the goals are to provide adequate feed intake of energy and carbohydrates to replenish muscle glycogen and ensure a rapid recovery [76]. As Coelho said (2004), for an optimum resynthesis, it should be noted the rate or amount, frequency and period of ingestion, as well as the type of carbohydrate [77]. The variables to be controlled depend on the duration and intensity of physical effort and the recovery period until the next workout.

Wong (2000) reported the effects of different types of carbohydrates in nine athletes which have been divided into two groups, one supplemented with carbohydrate (maltodextrin) and the other with placebo (PL). Everyone ran up to $70 \%$ VO2 max. on a treadmill for 90 minutes and then they had 4 hours of recovery. In the first three hours of this phase, the athletes' first group got supplemented by an ingestion of $6.9 \%$ solution of $\mathrm{CHO}$ and the athletes from the other group drank a placebo solution, both every 30 minutes. The results showed that the intake of $\mathrm{CHO}$ solution was more effective in restoring resilience compared to placebo [78]. 
According to Ivy (2004), muscle glycogen is essential for intense exercise, and thus it is known that the competitive sports require multiple daily training sessions or competitions on consecutive days, it is fundamental to apply strategies of rapid restoration of glycogen [79].

Based on Jentiens and Jeukendrup opinion (2003), if there is not carbohydrate replacement during the first hours after the exercise, the resynthesis can decrease by approximately $50 \%$ [75].

In the study made by Kovacs (2002) were verified the effects of consumption of solutions with high and low concentrations of $\mathrm{CHO}$ during the period of post-exercise rehydration and the related consequences. Eight trained cyclists were dried to $3 \%$ by weight of the cycle ergometer. During the recovery period, solutions of $60 \% \mathrm{CHO}, 40 \%$ and $20 \%$ in the first, second and third order respectively $(\mathrm{H})$ or $24 \%$ were ingested during 5 hours after the exercise $(\mathrm{L})$ [80]. It was concluded that during treatment $\mathrm{H}$ had a more rapid restoration of the proportion of plasma volume and fluid balance compared with L. According to Lancha Jr. (2002), glycogen is depleted after 2-3 hours of continuous exercise at an average intensity (60-80\% VO2max.), or 25 to 30 minutes of intense interval workouts (90-130 VO2max.) [10]. Athletes undergoing exhaustion present a reduction of intramuscular glycogen concentrations up to $100 \mathrm{Mm} / \mathrm{kg}$. (130 mm/kg for $30 \mathrm{mM} / \mathrm{kg})$.

In Ivy's studies (2004) for optimizing muscle glycogen resynthesis should be ingested 1.2 to $1.4 \mathrm{~g} / \mathrm{kg}$ of body weight with intervals of 2 hours, 0.6 to $0.7 \mathrm{~g} / \mathrm{kg}$ of body weight per hour. Thus, the resynthesis can be maintained for a period of 8 hours with an efficiency of synthesis like $7 \mathrm{mml} / \mathrm{kg} / \mathrm{muscle}$ per hour [79]. Brazilian Society of Sports Medicine (2003) ----recommends the consumption of 0.7 to $1.5 \mathrm{~g} / \mathrm{kg}$ per hour and once in the first 4 hours after an intense exercise [81]. And, as Jentjens and Jeukendrup (2003), affirm that most part of the glycogen synthesis occurs after an immediate intake of $1.0-1.85 \mathrm{~g} / \mathrm{kg} / \mathrm{hr}$ at intervals of 15 to 60 minutes for a period of 5 hours [75].

Ivy (2004) argues that the optimal frequency for carbohydrate replacement is every 15 to 30 minutes, since the author's resynthesis is $30 \%$ higher than the replacement done every two hours. When given $0.4 \mathrm{~g} / \mathrm{kg}$ of body weight every 15 minutes, resynthesis ---around $10 \mathrm{mml} / \mathrm{kg} /$ hour in a dry muscle during the first 4 hours after the exercise [79].

Burini (2008) describes that the power get immediately after a prolonged exercise is extremely important because carbohydrate intake can decrease protein degradation of myofibrils and this can increase the synthesis of body proteins [82]. Besides carbohydrates ingested mainly in the first half hour, should be increased consumption of water, since in this way amounts to stimulate increases the production of urine and the excretion of unwanted substances from the body.

Regarding the type of carbohydrate consumed after exercise, Jentjens and Jeukendrup (2003), among other studies, suggest that carbohydrates that are simple, with a high glycemic index, such as glucose, sucrose and maltodextrin, these are most effective during the first 6 hours of recovery [75].

The carbohydrate intake after the completion of the exercise is critical for the restoration role of the muscle reserves and liver glycogen. The author recommends that consumption of 0.7 to $1 \mathrm{~g}$ of simple carbohydrate/kg of body weight within 2 hours after the exercise until 6 hours after the average intake of $600 \mathrm{~g}$ of carbohydrates per day [20].

According to Vieira (2007) fructose, even though simple, has a low glycemic index and it is recommended for the replacement of liver glycogen that is metabolized in the liver [72]. Also according to the authors, during restoration the complex carbohydrates can be as effective as the simple ones. Foods like white bread, cereals, baked potatoes, sugar and honey produce higher concentrations of glycogen in the early hours of recovery if compared with the moderate one, as masses, and the low, like milk and fruit. During the first two hours of recovery, the rate of resynthesis achieves $8 \%$ per hour, reducing by $5 \%$ in the next 20 hours.

Finally, for Vidal and Soler (2010) the speed with which the muscle can recover its glycogen reserves is closely related to three dietary factors: the time between the end of the year and the beginning of the intake of carbohydrates, the type chosen and amount ingested [4]. Based on recent studies, the authors suggest that after an exercise, like a training session or competition, the athlete should begin immediately drinking between 1.5-2 liters of water, which must be dissolved in, 50-70 grams of glucose or maltodextrin (assuming that the athlete weight is $70 \mathrm{~kg}$ ). Between 1 hour and 2 hours and a half later, is indicated the preparation of a meal containing, for example, a cold salad with rice, potatoes or boiled peas. Or the combination of a meat dish (eg. a beef steak or a grilled chicken breast) with rice or mashed potatoes. According to the studies it is also needed to be included foods like fruit yogurt, rice pudding, banana, fruit juice, raisins, and the energy drink that will be consumed during the following hours to make a total of 500 to 600 grams carbs.

\section{Conclusion}

It might be noticeable in the review that the quest in order to improve physical performance have led athletes to increasingly make use of dietary manipulations and nutrient intakes. The maintenance of muscle glycogen stores is extremely important for highperformance athletes, where regular physical training and proper nutrition can positively affect these reserves, increasing them.

Due to the evidence suggesting the importance of glycogen on performance, there is a great interest in maintaining inventories of muscle and liver glycogen, thus it is generally recommended a carbohydrate intake for athletes performing long term sports, due to their rapid metabolism [3]. 
Checking literature, we find a considerable amount of researches that studied the effects of nutritional ergogenic resources on exercise performance. Still discussing the proper nutrition and sufficient nutrient intake for the athlete, we may not obtain a standard formula, but may be correct that this amount would depend on the sport the athlete practices.

Through this study it can be verified that there are carbohydrates that are the staple food of certain regions of the planet. Moreover, according to McArdle (2003) there are four categories of carbohydrates: Monosaccharides (glucose, fructose, galactose), disaccharides (sucrose, lactose and maltose) oligosaccharides and polysaccharides (starch) which differ by the number of simple sugars together in the molecule [10].

Glucose, as demonstrated by Williams (2002) and Lancha (2002) is the most important monosaccharide; since most of the carbohydrates is broken down to reach the glucose transported by the blood. Glucose going into the bloodstream may be converted into muscle or liver glycogen, and the amount absorbed in excess is converted into fatty acids and triglycerides, into liver and adipose tissue $[9,15]$.

In addition, blood glucose levels must be maintained high during endurance exercise.

A diet low in carbohydrates leads to a rapid consumption of liver and muscle glycogen which instantly affects the realization of an high-intensity anaerobic exercise or an aerobic exercise with long duration.

Thus, especially for athletes, is required the use of a diet in order to have an alimentation rich in carbohydrates before practicing exercise which increases glycogen storage, both muscular and hepatic $[1,16]$.

It is of paramount importance, according to literature, a rich supply of these nutrients during the training to succeed in the competition, because it is during this period that increases energy expenditure and consequently occurs an increase in caloric intake to maintain the body weight and the proper functioning of the body.

Checking several studies, it is concluded that the yield on prolonged exercise could be associated with the availability of carbohydrates available in form of glucose.

As seen in Wolinsky \& Hickson's (1996) and Mamus' (2006) studies the goal of a high-carbohydrate diet, in pre-competition phase, is to increase stored glycogen and prevent its depletion when the training is conducted thoroughly by successive days [5,14].

Furthermore, the possible mechanisms including the improvement of the performance involve an increased use of exogenous carbohydrates with a consequent saving of muscle glycogen. It has been found in some studies that fructose adds a supplement of glucose, increasing the levels of lactate rest. Additionally, by having a low glycemic index (LGI), fructose presents important features that support this statement as pre-exercise supplement, in addition to assessing improvement in performance, prolonging time until exhaustion. Such supplements may be provided in solid or liquid form.

Current recommendations for supplementation of carbohydrates as seen in studies of [6] are based on the potential benefit of prescribing low-glycemic carbohydrates (LGC), between 1-2 g. $\mathrm{kg}^{-1}$ pre-event between 1-3 hours before.

Consuming carbohydrates during exercise can improve athletic performance. The amount of carbohydrates that should be consumed also varies among authors. Viebig (2010) advocates the use for prevention of hypoglycemia and against reduction of the performance in athletes during exercise [7].

The initial goal of the diet after a competition is to rehydrate, restore glycogen stores and restore electrolyte balance [3]. The main aspect of the recommendations focused on the synthesis of glycogen in order to replenish the energy substrate oxidized during exercise [6].

As this process depends on the supply of carbohydrate and insulin concentration, those with moderate to high GI, are the most related to the efficiency of this metabolic process. Some authors believe that to maximize muscle glycogen resynthesis should be ingested 1.2 to $1.4 \mathrm{~g} / \mathrm{kg}$ of body weight at intervals of 2 hours, 0.6 to $0.7 \mathrm{~g} / \mathrm{kg}$ of body weight per hour. The Brazilian Society of Sports Medicine (2003) recommends the consumption of 0.7 to $1.5 \mathrm{~g} / \mathrm{kg}$ per hour and once the first 4 hours after an intense exercise [81]. Importantly, the power immediately after prolonged exercise is extremely relevant because carbohydrate intake can decrease protein degradation of myofibrils and can increase the synthesis of body protein. Besides, carbohydrate ingested mainly in the first half hour, should be increased the consumption of water, since in this way these amounts will stimulate an increased production of urine and will increase the excretion of unwanted substances from the body. growing number of participants in long-term and similars, there are clear advances of science in pre-competition nutrition. Still, there are now several studies seeking new nutritional interventions with carbohydrates and lipids. This review has also found that there are numerous studies seeking for a definition of the optimal amount of carbohydrates that improves physical performance.

Light on this evidence, this review finds its original objectives, reviewing the physiological and biochemical concepts and definitions of the discussing carbohydrates and carbohydrate intake/day, with all the major studies related to carbohydrate intake and physical performance, before, during and after competition, selected from a pre-established methodology.

Literature reviews are important connectors that have been studied pointing where the science must advance. More researches should be done to get the ideal carbohydrate intake for each sport: triathlon, marathon, marathons aquatic sports of long duration, because in every sport there are peculiarities that affect the athlete's performance. 


\section{References}

1. Cyrino ES, Zucas SM (1999) Influência da ingestão de carboidratos sobre o desempenho físico. Revista da Educação Física/ UEM 10: 73-9.

2. Nelson DL, COX MM (2006) Lehninger Princípios de Bioquímica. São Paulo: Sarvier.

3. Mamus RT, Santos MG (2011) A influência dos carboidratos sobre a performance física de triatletas. EF Deportes.com, Revista Digital. Buenos Aires, Ano 16, № 161 , Out.

4. Vidal JM, Soler SV (2010) La alimentación y su relación con el rendimiento físico. Revista Digital - Buenos Aires - Ano 15 - No 144 - Maio de.

5. Mamus R, Santos MG (2006) Efeitos bioquímicos da suplementação de carboidratos após uma competição simulada de Short Duathlon Terrestre. Revista Portuguesa Ciência Desportiva 6: 29-37.

6. Rossi L, Nacif M (2009) Importância e aplicação prática do índice glicêmico na competição. Nutr Profissional 23: 48-54.

7. De Sanctis F, Uemura CA, Nishimura CC, Viebig RF (2010) Carboidratos e sua importância no desempenho físico. Revista Digital - Buenos Aires - Ano 14 - No 141.

8. McArdle WD, Katch FI, Katch VL (2001) Nutrição para o desporto e o exercício. Rio de Janeiro: Guanabara-Koogan.

9. Lanchar JR AT (2002) Nutrição e Metabolismo: aplicados à atividade física. São Paulo Phorte.

10. McArdle WD, Katch FI, Katch VL (2003) Nutrição para o desporto e o exercício. Rio de Janeiro: Guanabara-Koogan.

11. Vieira R (2003) Fundamentos da Bioquímica. Belém-Pará.

12. Muccilo RCST (2009) Caracterização e Avaliação de Amido Nativo e Modificado de Pinhão Mediante Provas Funcionais e Térmicas. Tese de Doutorado Porto Alegre.

13. Berg JM, Tymoczko JL, Stryer L (2007) Biochemistry 6a ed, New York.

14. Wolinsky I, Hickson JR JF (1996) Nutrição no Exercício e no Esporte. 2º ed, São Paulo Roca.

15. Wong SH, Williams C, Adams N (2002) Effects of ingesting a large volume of carbohydrate-electrolyte solution on rehydration during recovery and subsequent exercise capacity. Int J Sports Nutr Exerc Metab 10: 234-40.

16. Rodriguez Y (2005) Necessidades Nutricionais em atletas. Instituto de Educação Superior de Brasília.

17. Mamus RT (2004) Efeitos Bioquímicos da suplementação de carboidratos em uma competição simulada de short duathlon terreste. Dissertação de Mestrado Curitiba.

18. Grandjean AC, Schroeder LJ (1994) A nutrição para atletas. Sprint 32-3.

19. Carter J, Jeukendrup AE, Mundel T, Jones DA (2003) Carbohydrate supplementation improves moderate and high-intensity exercise in the heat. Pflugers Arch 446: 211-9.

20. Rogatto GP, Luciano E (2001) Efeitos do treinamento físico intenso sobre o metabolismo de carboidratos.Revista Atividade Física e Saúde - Universidade Estadual Paulista: 6.

21. Dill DB, Edwards HT, Talbott JH (1932) Studies in muscular activity. VII. Factors limiting the capacity for work. J Physiol 77: 49-62.

22. Kreider RB, Wilborn CD, Taylor L (2010) ISSN Exercise and sport nutrition review: research and recommendations. J Int Socie Sport Nutri.

23. Tales de Carvalho (2003) Diretriz Da Sociedade Brasileira De Medicina Do Esporte. Modificações dietéticas, reposição hídrica, suplementos alimentares e drogas: comprovação de ação ergogênica e potenciais riscos para a saúde. Revista Brasileira de Medicina do Esporte 43-55.

24. Gomes RTM, Dos Santos MGA (2011) Influência dos carboidratos sobre a performance física de triatletas. Efdeportes.com, revista digital. Buenos Aires. 25. Newsholme EA (1999) An introduction to the roles of the glucose-fatty acid cycle in sustained exercise. In: Hargreaves M, Thompson M, ed. Biochemistry of exercise IX, 185 - 200. Champaign, IL: Human Kinetics 119-25.

26. Spriet LL (2007) Regulation of substrate use during the marathon. Sports Med 37: 332-6.

27. Joyner MJ, Coyle EF (2008) Endurance exercise performance: the physiology of champions. J Physiol 586: 35-44.

28. Kleiner SM (2002) Nutrição para o Treinamento de Força. São Paulo Manole.

29. American Dietetic Association, Dietitians of Canada, American College of Sports Medicine, 2001.

30. Panza VP, Coelho MSPH, Di Pietro PF (2007) Consumo alimentar de atletas: reflexões sobre recomendações nutricionais, hábitos alimentares e métodos para avaliação do gasto e consumo energéticos. Rev Nutr 20: 681-92.

31. Katch FI (2001) Nutrição para o desporto e o exercício. Rio de Janeiro: Guanabara-Koogan.

32. García-Rovés PM, Terrados N, Fernández SF, Patterson AM (1997) Macronutrients intake of top level cyclists during continuous competition-change in the feeding pattern. Int J Sports Med 19: 61-7.

33. Sapata KB, Fayh APT, De Oliveira AR (2006) Efeitos do consumo prévio de carboidratos sobre a resposta glicêmica e desempenho. Rev Bras Med Esporte: 12.

34. Wolinsky I, Hickson JR (2002) Nutrição no exercício e no esporte. 2ª ed São Paulo: Roca.

35. Febbraio MA, Stewart KL (1996) CHO feeding before prolonged exercise: effect of glycemic index on muscle glycogenolysis and exercise performance. J Appl Physiol 81: 1115-20.

36. Febbraio MA, Chiu A, Angus DJ, Arkinstall MJ, Hawley JA (2000) Effects of carbohydrate ingestion before and during exercise on glucose kinetics and performance. J Appl Physiol 89: 2220-6.

37. Hargreaves M, Hawley JA, Jeukendrup A (2004) Pre-exercise carbohydrate and fat ingestion: Effects on metabolism and performance. J Sports Sci 22: 31-8.

38. Foster C, Costill DL, Fink WJ (1979) Effects of preexercise feedings on endurance performance. Med Sci Sports Exerc 11: 1-5.

39. Kirwan JP, O'Gorman D, Evans WJ (1998) A moderate glycemic meal before endurance exercise can enhance performance. J Appl Physiol1: 53-9.

40. Gleeson M, Maughan RJ, Greenhaff PL (1986) Comparison of the effects of pre-exercise feeding of glucose, glycerol and placebo on endurance and fuel homeostasis in man. Eur J Appl Physiol Occup Physiol 55: 645-53.

41. Billat LV (1996) Use of the lactate measurements for prediction of exercise performance and for control of training. Recommendations for long-distance running. Sports Med 22: 157-75. 
42. Shiota M, Moore MC, Galassetti P, Monohan M, Neal DW, et al. (2002) Inclusion of low amounts of fructose with an intraduodenal glucose load markedly reduces postprandial hyperglycemia and hyperinsulinemia in the conscious dog. Diabetes 51: 469-78.

43. Lê KA, Tappy L (2006) Metabolic effects of fructose. Curr Opin Clin Nutr Metab Care 9: 469-75.

44. DE SÁ CA, Fernandez JM, DA Silva-Grigoletto ME (2010) Respostas metabólicas à suplementação com frutose em exercício de força de membros inferiores. Rev Bras Med Esporte.

45. Ruby BC, Coggan AR, Zderic TW (2002) Gender differences in glucose kinetics and substrate oxidation during exercise near the lactate threshold. J Appl Physiol 9: 1125-32

46. Rodriguez Y (2004) Necessidades Nutricionais em atletas. Instituto de Educação Superior de Brasília.

47. Guerra I (2002) Importância da alimentação do atleta visando a melhora da performance. Revista Nutrição em Pauta 4: 63-6.

48. Chryssanthopoulos C, Williams C, Nowitz A, Bogdanis G (2004) Skeletal muscle glycogen concentration and metabolic responses following a high glycaemic carbohydrate breakfast. J Sports Sci 24: 1065-71.

49. Wilmore JH, Costill DL (2001) Fisiologia do esporte e do exercício. 1aed São Paulo Manole.

50. García-Rovés PM, Terrados N, Fernández SF, Patterson AM (1997) Macronutrients intake of top level cyclists during continuous competition-change in the feeding pattern. Int J Sports Med 19: 61-7.

51. Clark VR, Hopkins WG, Hawley JA, Burke LM (2000) Placebo effect of carbohydrate feedings during a 40-km cycling time trial. Med Sci Sports Exerc 32: $1642-7$.

52. Ferreira AMD, Ribeiro BG, Soares EA (2001) Consumo de carboidratos e lipídios no desempenho em exercícios de ultra-resistência. Rev Bras Med Esporte.

53. Tarnopolsky MA, Bosman M, Macdonald JR, Vandeputte D, Martin J, et al. (1997) Postexercise protein-carbohydrate and carbohydrate supplements increase muscle glycogen in men and women. J Appl Physiol 83: 1877-83.

54. Hawley JA, Brouns F, Jeukendrup A (1998) Strategies to enhance fat utilization during exercise. Sports Med 25: 241-57.

55. Williams C, Devlin JT (1992) Foods, nutrition and sports performance: an international scientific consensus organized by Mars, Incorporated with International Olympic Committee patronage. London: E \& FN SPON.

56. Rossi L (2011) Carboidratos e novos paradigmas para aplicação no esporte. Nutrição Profissional 32: 46-9.

57. Wasserman DH, Abumrad NN (1989) Physiological bases for the treatment of the physically active individuals with diabetes. Sports Med 7: 376-92.

58. Burke LM, Kiens B, Ivy JL (2004) Carbohydrates and fat for training and recovery. J Sports Sci 22: 15-30.

59. Tarnopolsky MA (2000) Gender differences in substrate metabolism during endurance exercise. Can J Appl Physiol 25: 312-27.

60. Jentjens RL, Shaw C, Birtles T, Waring RH, Harding LK (2005) Oxidation of combined ingestion of glucose and sucrose during exercise. Metabolism 54: 610-8. 61. Ruby BC, Coggan AR, Zderic TW (2002) Gender differences in glucose kinetics and substrate oxidation during exercise near the lactate threshold.Journal of Applied Physiology 92: 1125-32.

62. Péronnet F, Burelle Y, Massicotte D, Lavoie C, Hillaire-Marcel C (1997) Respectiveoxidation of 13C-labeled lactate and glucose ingested simultaneously duringexercise. J Appl Physiol 82: 440-6.

63. Riddell MC, Bar-Or O, Ayub BV, Calvert RE, Heigenhauser GJ (1999) Glucose ingestion matched with total carbohydrate utilization attenuates hypoglycemia during exercise in adolescents with IDDM. Int J Sport Nutr 9: 24-34.

64. Billat LV (1996) Use of the lactate measurements for prediction of exercise performance and for control of training. Recommendations for long-distance running. Sports Med 22: 157-75.

65. Kawanaka K, Tabata I, Katsuta S, Higuchi M (1997) Changes in insulin-stimulated glucose and GLUT-4 protein in rat skeletal muscle after training. J Appl Physiol 83: 2043-7.

66. McArdle WD, Katch FI, Katch VL (1999) Nutrição para o desporto e o exercício. Rio de Janeiro: Guanabara-Koogan.

67. Jentjens RL, Achten J, Jeukendrup AE (2004) High oxidation rates from combined carbohydrates ingested during exercise. Med. Sci. Sports Exerc 36: 1551-8.

68. Diretriz Da Sociedade Brasileira De Medicina Do Esporte (2003) Modificações dietéticas, reposição hídrica, suplementos alimentares e drogas: comprovação de ação ergogênica e potenciais de riscos para a saúde. Rev Bras Med Esporte 9: 43-55.

69. Guerra I (2002) Importância da alimentação do atleta visando a melhora da performance. Revista Nutrição em Pauta 4: 63-6.

70. Lambert EV, Hawley JA, Goedecke J, Noakes TD, Dennis SC (1997) Nutritional strategies for promoting fat utilization and delaying the onset of fatigue during prolonged exercise. J Sports Sci 15: 315-24

71. NakataniA, Han D, Hansen PA, Nolte A, Host HH, et al.(1997) Effect of endurance training on muscle glycogen supercompensation in rats. J Appl Physiol 82: 711-5.

72. Vieira AK (2007) Mecanismos e estratégias para a ressíntese deglicogênio muscular após o exercício de resistência. Revista Digital - Buenos Aires - Ano 12 $\mathrm{N}^{\circ} 115$-Dez.

73. Greiwe JS, Holloszy JO, Semenkovich CF (2000) Exercise induces lipoprotein lípase and GLUT-4 protein in muscle independent of adrenergic-receptor signaling. J Appl Physiol 89: 176-81.

74. Nakatani A, Han DH, Hansen PA, Nolte LA, Host HH, et al. (1997) Effect of endurance training on muscle glycogen supercompensation in rats. J Appl Physiol 82: 711-5.

75. Jentjens R, Jeukendrup A (2003) Determinants of post-exercise glycogen synthesis during short-term recovery. Sports Medicine 117-44.

76. American College of Sports Medicine (2000) Nutrition and athletic performance- Joint Position Statement. Med Sci Sports Exerc 32: 2130-45.

77. Coelho CF, Sakzenian VM, Burini RC (2004) Ingestão de carboidratos e desempenho físico. Revista Nutrição em Pauta 51-6.

78. Wong SH, Williams C, Adams N (2000) Effects of ingesting a large volume of carbohydrate-electrolyte solution on rehydration during recovery and subsequent exercise capacity. Int J Sports Nutr Exerc Metab 10: 234-40.

79. Ivy JL (2004) Regulation of muscle glycogen repletion, muscle protein synthesis and repair following exercise. J Spor and Medici 131-8.

80. Kleiner SM (2002) Nutrição para o Treinamento de Força. São Paulo Manole. 
81. Brazilian Society of Sports Medicine.

82. Burini CR, Coelho FC, Sakzenian MV (2008) Ingestão de Carboidratos e Desempenho Físico. Nutrição em Pauta 67: 51-6.

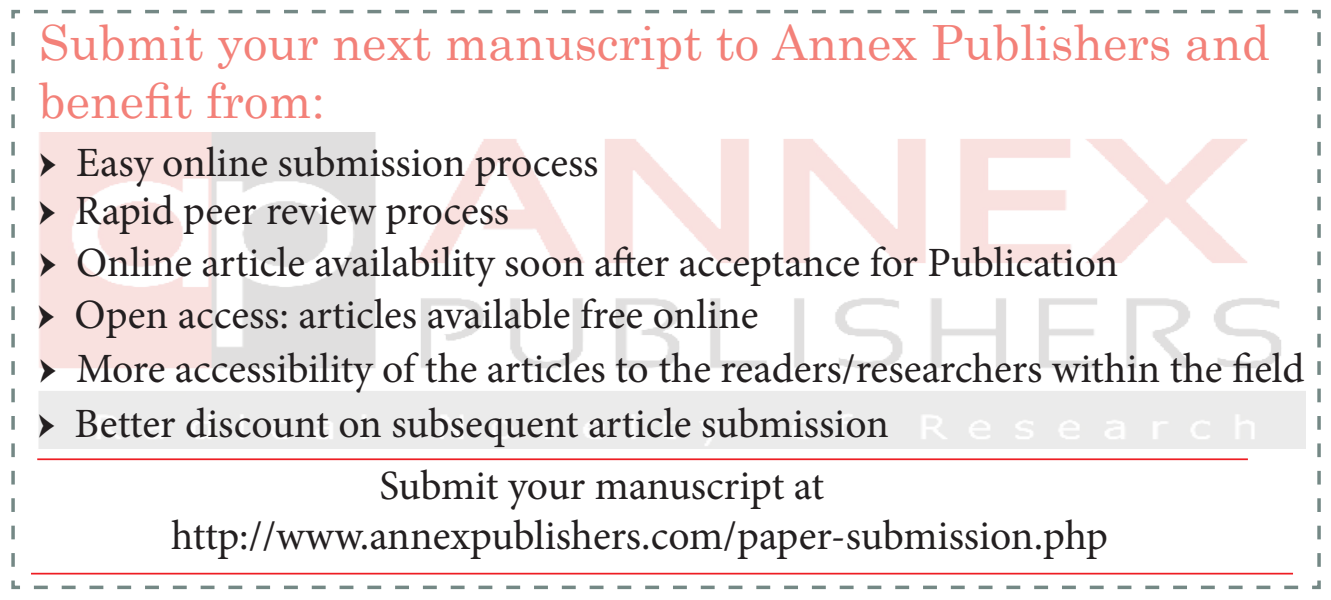

